DOI: $10.2478 / \mathrm{v} \cdot 10169-012-0021-0$

\title{
REUSE OF “END OF LIFE TYRES” TYRE CHIPS - SAND MIXTURE MECHANICAL STUDY
}

\author{
E. DEMBICKI ${ }^{1}$, M. KOWALCZYK ${ }^{1}$, P. GOTTELAND ${ }^{2}$
}

\begin{abstract}
The use of shredded tyre in civil engineering applications is a significant potential end use market. The reuse of tyre chips may not only address growing environmental and economic concerns, but also help to solve geotechnical problems associated with low shear strength. The purpose of this paper is to investigate the properties of tyre chips and tyre chips - sand mixture, and to find the mixture with the highest shear strength. In this study, an experimental testing program was undertaken using a large - scale triaxial apparatus with the goal of evaluating the optimum percentage of tyre chips in sand. The effects on shear strength of varying percentage of tyre chips and varying confining pressure were studied. Tyre chips content was suspected to have influence on stress - strain and volumetric strain behaviour of the mixture. Some tests were conducted to check the influence of number of used membranes, of saturation and compaction, on sample properties.
\end{abstract}

Key words: Materials, Tyre chips-sand mixture, Laboratory research, Test Results, Conclusion.

\section{INTRODUCTION}

Every year about 2600000 tonnes of used tyres (part worn + end of life tyres) are generated in Europe, of which 2000000 tons are end-of-life tyres (source: BLIC). When ten new countries joined European Union the number of used tyres increased to 3100000 tones, and more than 130000 tones were carried in by Poland.

\subsection{EuRopean Directives}

End of life tyres are classified in the EC Decision on EU list of wastes (2001/118), under entry 16.01.03. The "End of life tyre" is a non-reusable tyre in its original form. It enters a waste management system based on product/material recycling, energy recovery or goes to landfill. Three directives concerning used tyres were established by European Parliament. The first one The Directive on the Landfill of Waste (1999/31/EC) of April 1999 lays down a ban of whole tyres by 16 July 2003 and of shredded tyres

${ }^{1}$ Faculty of Civil and Environmental Engineering, Gdansk University of Technology, ul. G. Narutowicza 11/12, 80-233 Gdańsk, Poland, e-mail: edemb@pg.dga.pl

${ }^{2}$ University Joseph Fourier, Grenoble, France 
by 16 July 2006. Exemptions were obtained by BLIC members for the use of whole tyres for engineering purposes, bicycle tyres and tyres above $1400 \mathrm{~mm}$ diameter. Tyre producers are intensively working on the achievements of these targets not only in Member States but also in expected new EU members. The second one, which is called The Directive on End of Life Vehicles (2000/53/EC) although making little reference to tyres, has a significant impact on the Sector. The Directive lays down measures aiming at preventing vehicles waste promoting reuse, recycling, and other forms of recovery of end of life vehicles and their components. To this end, it sets recycling and recovery targets to be achieved by 2015 and which are destined also to tyres. The third directive called The Directive on Incineration of waste (2000/76/EC/ of December 2000 fixes emission limits for all new cement kilns from end -2002. From December 2005, new provisions shall apply to cement kilns co-incinerating waste including "end of life tyres". Old cement kilns will not be able to burn tyres after 2008, the overall capacity being reduced by approximately $10 \%$.

The Directives on Landfill and "end of life tyres" place limits on the landfilling for "end of life tyres". These have been acting as a powerful driving force to increase recovery measures and to reinforce the industry actions. Thanks to such involvement, the recovery of "end of life tyres" has become increasingly common in Europe with a recovery rate in Western Europe of 82\% in 2003. This compares to 50\% in 1992. The high recovery rate means that less and less "end of life tyres" are being used as landfill or ending up in unknown management routes (BLIC, Annual Report 2004-2005).

\subsection{DANGER AND PROBLEMS OF STOCKPILING}

The disposal and storage of end of life tyres has a number of potential adverse environmental and health impacts. When whole tyres are stored they cause practical difficulties. They trap gases and can slowly 'float' to the surface. Placing whole tyres in landfills leads to the available space being filled quickly, and the landfill potentially becoming unstable. As a result the landfill management is more difficult and costly. Water pooled in tyres provides an ideal breeding ground for some types of mosquito, which can be dangerous for people health. It is also a place, where other disease caring vermin, like for example rats, can well exists. The risk of tyre fires is great and tyre fires produce hazardous air emissions and toxic effluents, which have adverse health and environmental implications. Those facts show that it is necessary to find new ways of recycling "end of life tyres".

\subsection{Civil Engineering application}

The civil engineering applications market encompasses a wide range of uses for tyre chips and whole tyres. In almost all applications tyre chips replaces some other materials currently used in constructions such a lightweight fill materials like expanded shale or polystyrene insulation blocks, drainage aggregate, or even soil or clean fill. Tyre 
chips have unique properties such as durability, strength, resiliency, and high frictional resistance, which are useful for many geotechnical and geoenvironmental applications. This market has a good potential for development but this depends largely on ability of the industrial players involve to convince the authorities and constructors. It is believed that civil applications hold the greatest promise for "end of tyres" market opportunities, because for every project of civil engineering a large number of tyres can be used.

Shredded tyres can be used in several landfill applications - as a daily cover, in the landfill drainage layer, as part of the landfill cap, and to assist landfill gas venting. Tyre chips have been used in new landfill constructions in the bottom layer to provide drainage in leachate collection systems. There is a risk of fire if shredded tyres are not installed properly. The risk of spontaneous combustion is very low, when tyres are laid as a landfill drainage layer less than 1 meter thick. Some examples of tyre fires made new questions about using tyres in the linear layer of landfill constructions.

Shredded tyres are a suitable material for a light weight fill, especially on top of weak soils, for subgrade fill and for constructions of bridge embankments, road embankment, retaining wall reinforcements and for other projects. Shredded tyres can be substituted for materials, such as gravel and sand. They are viable in these applications due to their light weight. For most projects, using tyre chips as a lightweight material is significantly cheaper than alternatives. The weight of tyre chips reduces horizontal pressure and allows for construction of thinner, less expensive walls. Tyre chips can also reduce problems with water and frost build up behind walls because they are free draining and they provide good thermal insulation.

Tyre chips can replace aggregate or stone in the road base layer of the road construction projects. They have been used in such application for years and there were some tyre fires noted. Fires were caused by using tyres at too great thickness level. New standards have significantly reduced the risk of spontaneous combustion of tyre used as an aggregate substitute in road base.

In climates where excess water is released when subgrade soils thaw in the spring, placing a $15-30 \mathrm{~cm}$ thick tyre chips layer under the road cap prevents it from freezing in the first place. The high permeability of tyre chips allows water to drain from beneath the roads, preventing damage to the road surface.

Shredded tires can even be used to clean up hazardous waste sites. For example, at many sites where contaminated groundwater exists, a groundwater cut-off wall (or "slurry" wall) is installed to slow the flow of contaminants. Most of these "slurry" walls are constructed by backfilling a deep trench with soft clay.

Shredded tyres have high hydraulic conductivity. They allow water to drain easily. According to RMA (www.rma.org), tires show ten times better drainage properties than soil and eight times better insulation properties than gravel. Shredded tires can be used in many drainage projects. For example as a backfill around effluent leach field piping in septic systems. Tyre shreds replace traditional stone backfill material, can also hold more water than stone, and can be transported more easily due their light weight. Challenges to using tyre shreds in drain fields include their quality. They must be clean 
cut and be of uniform size. It is necessary to consider leaching properties of tyre shreds when they have contact with water, since tyre shreds contain an amount of iron.

\section{Materials}

\subsection{SAND}

The materials used in this research program were sand and shredded rubber tyres (tyres chips). The testing program was conducted on Hostun sand, a reference sand widely used in France. The unit weight of soil particles is $\gamma_{s}=2,65\left[\frac{\mathrm{kN}}{\mathrm{m}^{3}}\right]$ and friction angle was determined to be $39^{\circ}$. The grain-size distribution is shown on Fig. 1.

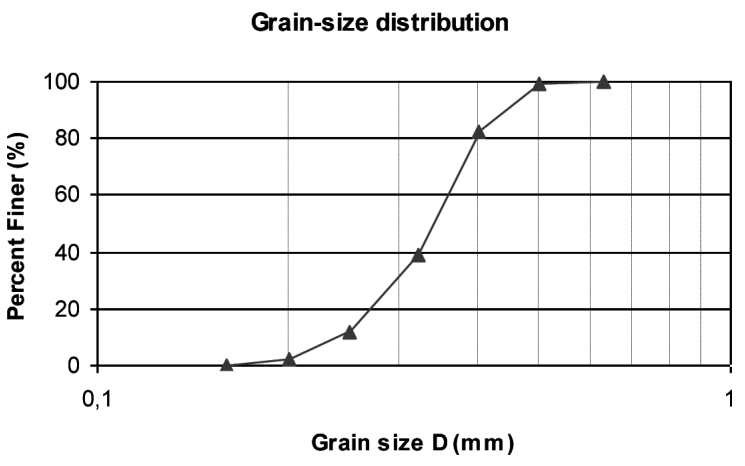

Fig. 1. Grain - size distribution of sand.

2.2. TYRE CHIPS

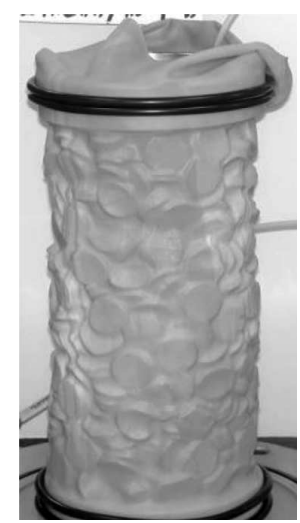

Fig. 2. Specimen made of pure tyre chips. 
Tyre chips have unique properties for many geotechnical and geoenvironmental applications, such as durability, resiliency, and high frictional resistance. Another advantage is their light weight. It makes them an appropriate material for using as a lightweight embankment fill over soft or unstable ground and retraining wall backfills. They also have some disadvantages, such as a tendency to exothermic reactions and high compressibility which can compromise the serviceability of the geotechnical structures.

Table 1

Summary of results.

\begin{tabular}{|c|c|c|}
\hline $\begin{array}{c}\text { Confining } \\
\text { pressure }\end{array}$ & $\begin{array}{c}\text { Deviator stress at } \\
\mathbf{1 0 \%} \text { of strain }\end{array}$ & Density \\
\hline$[\mathrm{kPa}]$ & {$[\mathrm{kPa}]$} & {$\left[\frac{\mathrm{kg}}{\mathrm{m}^{3}}\right]$} \\
\hline 40 & 91 & 679 \\
\hline 80 & 111,3 & 638 \\
\hline 120 & 144 & 651 \\
\hline
\end{tabular}

Stress-Strain (100\%tyres)

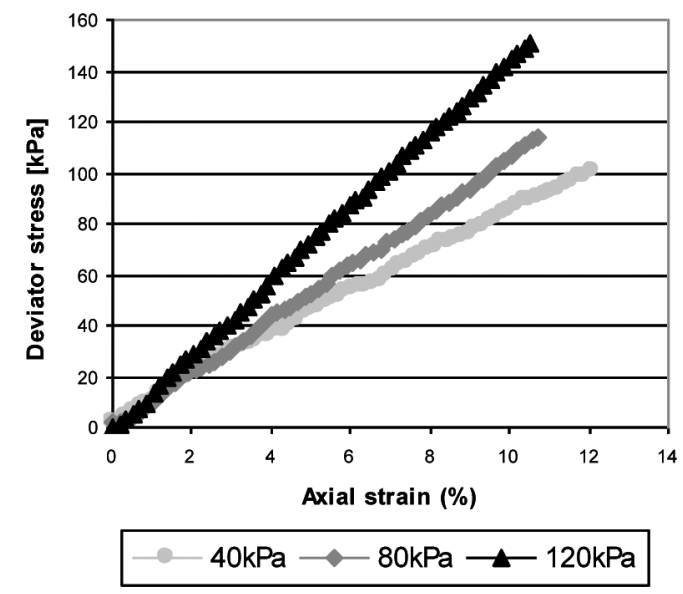

Fig. 3. Stress - strain relation.

The most important mechanical property of tyre chips, which makes them a potential material for geotechnical applications, is their high shear strength. In this testing program the shear strength of tyre chips, under three confining pressures, was investigated. The results are shown on figure 3 . This graph shows that the stress - strain relation for tyre chips is fully linear. There is no well defined peak. The shear strength was defined at $10 \%$ of strain. The highest value of the deviator stress was noted for the sample uder a confining pressure of $120 \mathrm{kPa}$ and was equal to $144 \mathrm{kPa}$. There 
Stress-Strain relation (100\%tyres)

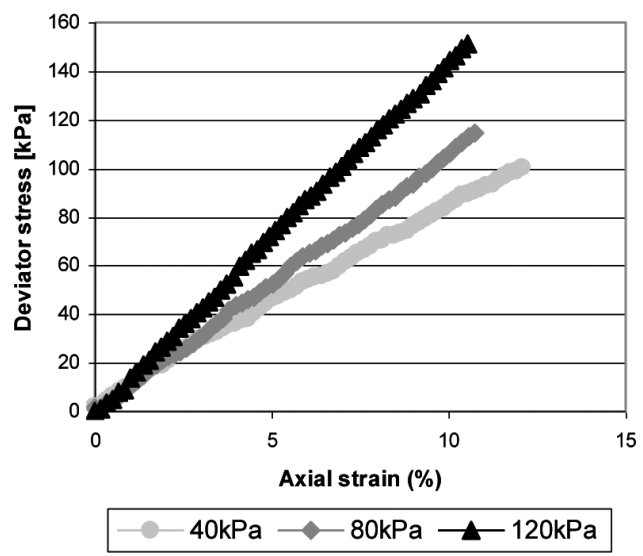

Fig. 4. Volume variation, pure tyre chips.

was only one test on specimens of $100 \%$ of tyre chips conducted for each confining pressure. Volume variations from those tests have approximately linear curse. In tests on this type of sample there is a very small difference between volume variations for different confining pressures. Volume variation of sand samples strongly depended on confining pressure. Figure 4 shows that in the case of samples with pure tyre chips such a dependence wasn't noted. The curves almost the same. Volume variation recorded during isotropic test shows that the volume varies greatly, when increasing the confining pressure. It is suspected that during increasing the stress, the volume variation is not much affected by confining pressure.

As reported in a statistical analysis of the investigation of different authors (Reddyk, 2001), the internal friction angle of waste tyres is in the range of $15^{\circ} \pm 33,7^{\circ}$. From the results of this investigation the friction angle of non compacted tyre chips specimens were determined to be $14,41^{\circ}$ and cohesion $24,95 \mathrm{kPa}$. On Figure 5 the results from "Rockdata" program, which was used to determine strength characteristics, is shown.

The tyre chips used in this investigation were produced by a factory financed by the French government in order to help in recycling "end of life tyres". This cactory - Helios Niko Pneus, Beaucaire, Languedoc-Rousillon, France produces tyre chips usung a punching method. In this method metal cylinders are forced to cut through tyres producing a material with a proportion of circular chips.

The shape of used tyres chips wasn't uniform, but most of pieces were round.

The diameter of round tyre chips was about $2,80 \mathrm{~cm}$. The thickness wasn't uniform, and was enclosed between $0,4 \mathrm{~cm}$ and $1,1 \mathrm{~cm}$. The medium one was equal to $0,7 \mathrm{~cm}$. The tyre chips didn't contain steel wires. Density of pure tyre chips is equal to $1150\left[\frac{\mathrm{kg}}{\mathrm{m}^{3}}\right]$. 


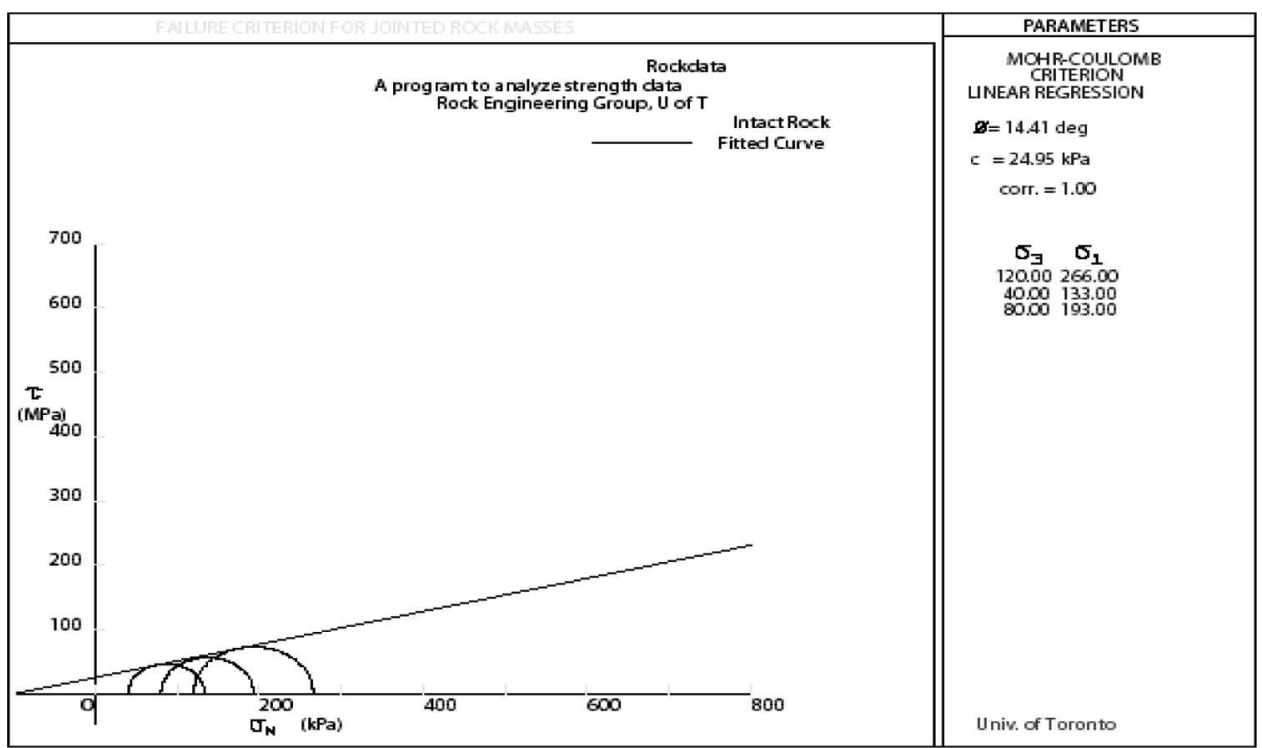

Fig. 5. Result from "Rockdata" program, pure tyre chips.

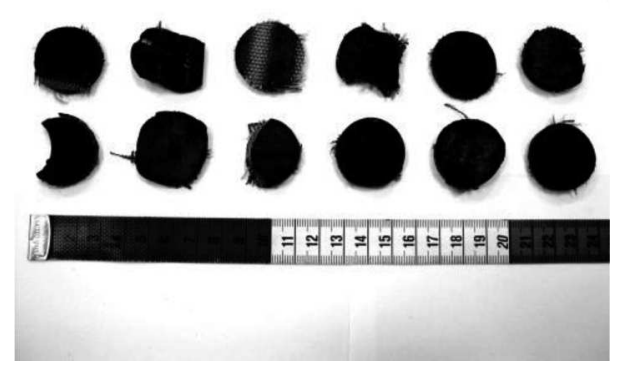

Fig. 6. The shape of tyre chips.

2.3. TyRe CHIPS - SAND MIXTURE

The objective of this study is to characterise the mechanical behaviour of tyre chips sand composite. Particular emphasis is placed on evaluation of the optimum percentage of tyre chips within the mixture. In addition, the influence of confining pressure on mechanical behaviour was investigated.

This investigation demonstrates the feasibility of using tyre chips to improve the mechanical properties of fill. Traditional soil reinforcing techniques involve the use of continuous geosynthetic inclusions (e.g. geogrids, geotextiles) oriented in a preferred direction to enhance the stability of the soil mass. Instead, the focus of this study is 
on randomly distributed inclusions, the effect of which is expected to lead to improved mechanical behaviour of the composite material.

There are some concerns about using pure tyres for permanent infrastructure. A disadvantage is their potential for exothermic reactions. The use of tyre chips - sand mixture is an alternative that would avoid exothermic reactions.

Pure tyre chips have high compressibility. When subjected to stress, a rubber chip particle in the mixture is deformed thereby reducing the void between the rubber tyre chip particles. Thus, the tyre chips - sand mixture has a lower compressibility compared to pure tyres. Combining sand with tyre chips can improve the deformation characteristics of tyre chips.

It can be read from Figure 7 that tyre chips content has a significant influence on the shear strength of the mixture. Tyre content also has an influence on volume variation, which is shown on Figure 8. The behaviour of specimens with tyre content higher than $30 \%$ is contractive. The shape of the curves of specimens with less than $30 \%$ of tyres (Figure 8) is similar to that of the shape of sand sample curves, and there is no big difference between volume variation of samples with $0 \%, 10 \%, 30 \%$ of tyres. For percentage enclosed between $0 \%$ and $30 \%$ the influence of tyre content on volume variation is negligible.

Stress - Strain $120 \mathrm{kPa}$

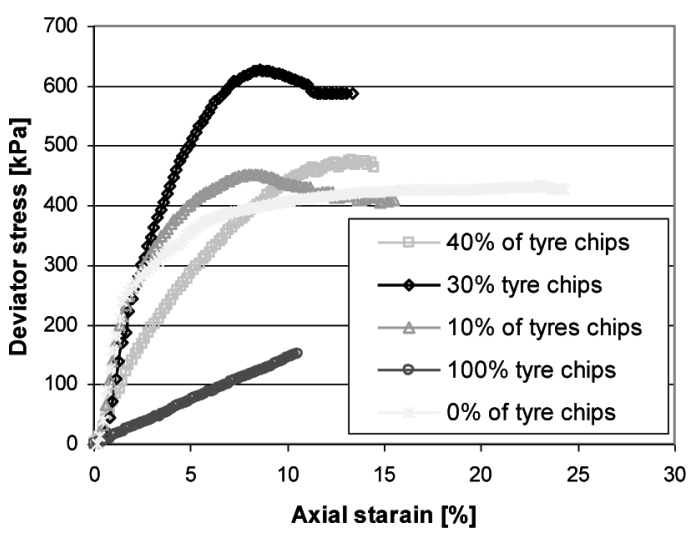

Fig. 7. Stress - strain relation, $120 \mathrm{kPa}$.

All mixtures have a well defined peak. For compound internal friction angle is enclosed between $38,51^{\circ}$ and $30,92^{\circ}$, and cohesion was evaluated to be between 14,08 $\mathrm{kPa}$ and $30,92 \mathrm{kPa}$.

The density of the mixture depends highly on tyre content. With increasing percentage of tyres chips density is decreasing. Average densities are shown in Table 2 and Figure 9. The highest density was observed for pure sand, and the lowest for pure tyre 
Volume variation $120 \mathrm{kPa}$

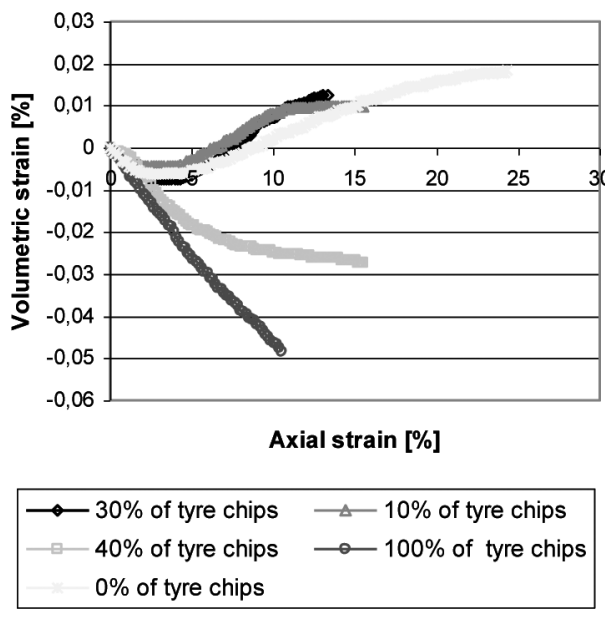

Fig. 8. Volume variation, $120 \mathrm{kPa}$.

chips. It is impossible to compact specimens with high tyre chips content, because it causes segregation of components. Segregation wasn't observed for tyre chips contents below and equal to $30 \%$.

Table 2

Density.

\begin{tabular}{|l|c|c|c|c|c|}
\hline & \multicolumn{5}{|c|}{ Tyre chips content in the mixture } \\
\hline & $\mathbf{0 \%}$ & $\mathbf{1 0 \%}$ & $\mathbf{3 0 \%}$ & $\mathbf{4 0 \%}$ & $\mathbf{1 0 0 \%}$ \\
\hline Density $\left[\frac{\mathrm{kg}}{\mathrm{m}^{3}}\right]:$ & 1489 & 1416 & 1405 & 1235 & 656 \\
\hline
\end{tabular}

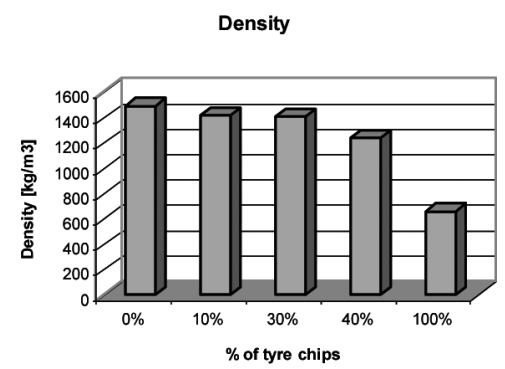

Fig. 9. Density.

Different percentages of tyres in sand were used. Sometimes it was proportion in mass and sometimes in volume. Used percentage: 
- $10 \%$ of tyre chips and $90 \%$ of sand - proportion in volume;

- $30 \%$ of tyre chips and $70 \%$ of sand - proportion in volume;

- $40 \%$ of tyre chips and $60 \%$ of sand - proportion in mass.

The mass of materials necessary to obtain a proper percentage in volume for samples with $40 \%$ tyres content was difficult to calculate because during preparation sand didn't fill voids between tyres placed accidentally. Despite proper volume mass of tyres and sand, in all attempts there was too much material. In this case the solution was to use percentage in mass. Proportion in volume was calculated.

The mass of tyre chips for each percentage was determined as follow:

$M_{T}=\% T \times V \times \rho[\mathrm{kg}]$

$M_{S}=\% S \times V \times \rho[\mathrm{kg}]$

where:

$M_{T}$ - mass of tyre chips [kg],

$M_{S}$ - mass of sand $[\mathrm{kg}]$,

$\% T$ - percentage of tyre chips,

$\% S-$ percentage of sand,

$V$ - volume of the sample $\left[\mathrm{m}^{3}\right]$,

$\rho$ - density $\left[\frac{\mathrm{kg}}{\mathrm{m}^{3}}\right]$.

When proportion in mass was used, the appropriate mass of materials was put in to the mould during preparation of the sample, by using balance. After, mass of used material was noted.

\section{Traxial test. Test Description}

A large triaxial cell was used to test the specimens with tyre chips - sand mixture, tyres and sand. Cylindrical specimens (diameter about $15 \mathrm{~cm}$ and height approximately $30 \mathrm{~cm}$ ) were composed of tested material and rubber membranes.

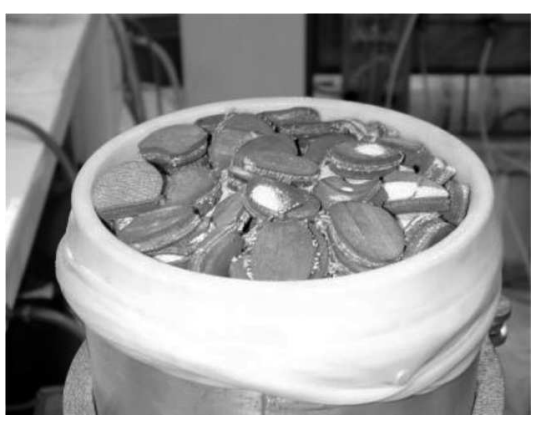

Fig. 10. Mould filled by mixture.

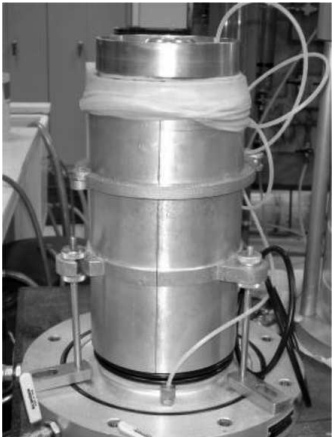

Fig. 11. Metal mould and the top cap. 


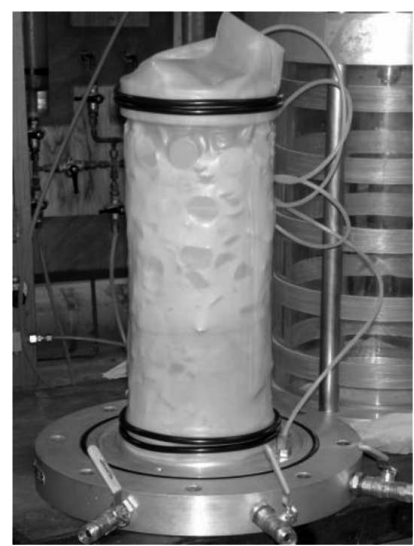

Fig. 12. Prepared sample.

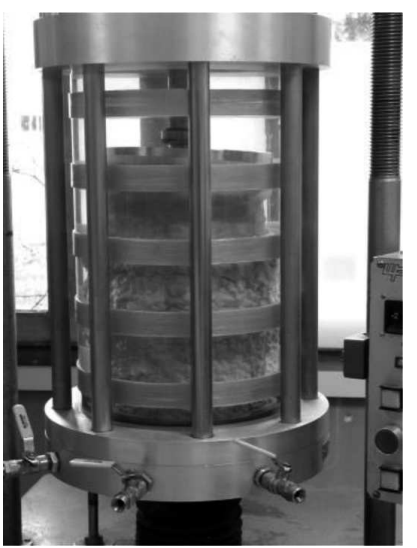

Fig. 13. Sample inside the cell.

Samples were placed in the compression chamber and subjected to confining water pressure. Three different confining pressures were used: $40 \mathrm{kPa}, 80 \mathrm{kPa}, 120 \mathrm{kPa}$. In the case of the test on the saturated sample, the specimen was saturated before loading under confining pressure $20 \mathrm{kPa}$ for stability of the sample. This low confining pressure minimized unrecorded volume changes during the saturation stage. During performing the test, the sample was loaded axially.

Compiled data led to characterisation of the deviator stress - strain, volume strain, and shear strength behaviour of specimens prepared using pure tyres, pure sand and tyre chips - sand mixture.

The test is called "traxial" because of three stresses which are assumed to be know. The most important stress $\sigma_{1}$ is equal to the axial stress during shearing. As $\sigma_{3}$ determines the pressure in chamber. The difference $\sigma_{1}-\sigma_{3}$ is termed deviator stress.

$\sigma_{1}$ and $\sigma_{3}$ are used to create Mohr's circles from which parameters such as friction angle $\Phi$ and cohesion c can be read. For sand c theoretically is expected to be zero.

Shear strength parameters, such as internal friction angle and cohesion, were determined by using "Rockdata" program.

Readings were taken manually from measuring apparatus. Displacement read from division clock was corrected to the loading. The load value was converted to $\mathrm{kg}$ and after to $\mathrm{kN}$ using a special curve relationship. Specimen under confining pressure was loaded axially with a speed $2 \mathrm{~mm} / \mathrm{min}$ until failure. Stress was calculated using constant section area without correction. In reality section area is changing during deformation but this phenomenon wasn't taken into account.

Volume variation was recorded by measuring water level in two tubes. The first tube showed changes of volume in the cell outside the sample (V out), the second one inside the sample ( $\mathrm{V}$ in). The diameter of the tubes was $5 \mathrm{~cm}$, so small changes of volume were imperceptible. 


\subsection{THE INFLUENCE OF MEMBRANES}

For preparing the sample one or two membranes were used. Using two membranes was necessary for protection because of used material type and economical reasons. The influence of number of membranes was verified. The difference between results on samples prepared with one membrane and with two membranes is not significant. Under confining pressure $80 \mathrm{kPa}$ the highest difference was equal to $10 \mathrm{kPa}$, and under $40 \mathrm{kPa}$ it was $21 \mathrm{kPa}$. This graph shows that using one or two membranes is irrelevant. They don't affect sand shear strength and volume variation (Fig. 14, 15) greatly, especially under high confining pressure.

Table 3

Summary of results.

\begin{tabular}{|c|c|c|c|c|}
\hline Name of curve & $\begin{array}{c}\text { Confining } \\
\text { pressure }\end{array}$ & $\begin{array}{c}\text { Number of } \\
\text { membranes }\end{array}$ & $\begin{array}{c}\text { Maximum } \\
\text { deviator } \\
\text { stress }\end{array}$ & Density \\
\hline- & {$[\mathbf{k P a}]$} & - & {$[\mathbf{k P a}]$} & {$\left[\frac{\mathrm{kg}}{\mathrm{m}^{3}}\right]$} \\
\hline 1 membrane $40 \mathrm{kPa}$ & 40 & $\mathbf{1}$ & 172 & 1487 \\
\hline 2 membrane $40 \mathrm{kPa}$ & 40 & $\mathbf{2}$ & 151 & 1496 \\
\hline 1 membrane $80 \mathrm{kPa}$ & 80 & $\mathbf{1}$ & 303 & 1502 \\
\hline 2 membrane $80 \mathrm{kPa} 1$ & 80 & $\mathbf{2}$ & 310 & 1501 \\
\hline 2 membranes $80 \mathrm{kPa} 2$ & 80 & $\mathbf{2}$ & 313 & 1475 \\
\hline
\end{tabular}

Comparis on of tests on sand with 1 membrane and 2 membranes stress - strain relation
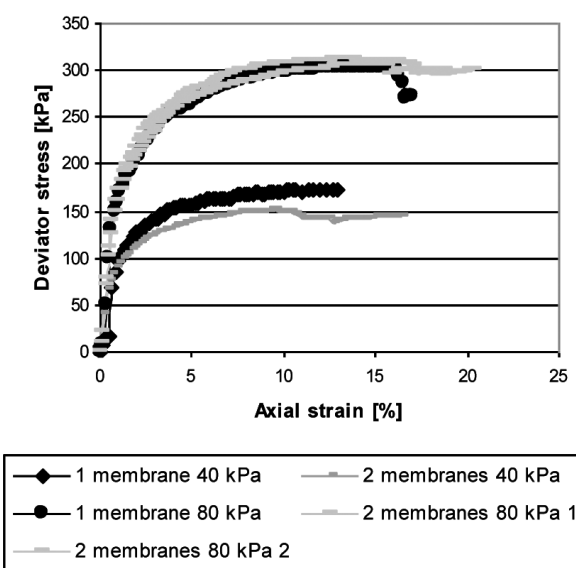

Fig. 14. Stress - strain relation, membranes.
Comparison of tests on sand with 1 membrane and 2 membranes volume variation

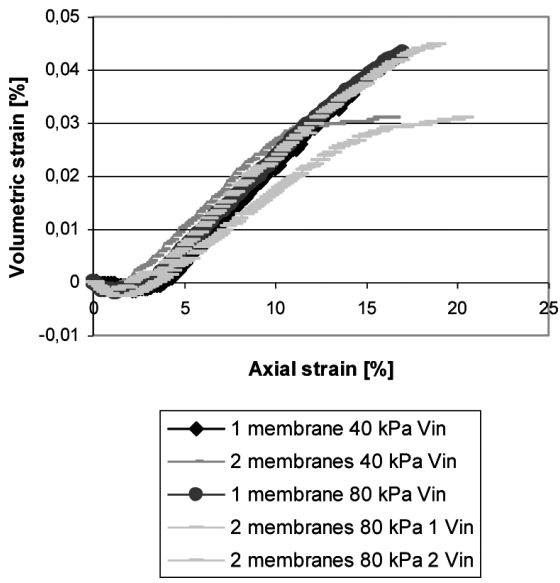

Fig. 15. Volume variation, membranes. 


\subsection{THE INFLUENCE OF COMPACTION}

Specimens were compacted using different procedures depending on the tyre chips content in the mixture. Segregation was not observed for low tyre chips content $(\leq 30 \%)$. Sample preparation used in this study was implemented to facilitate a random distribution of the tyre chips within specimen and to avoid components segregation. For percentage $10 \%, 30 \%, 0 \%$ of tyres and for pure sand, specimens were compacted. Compaction was completed in three $10 \mathrm{~cm}$ layers. Tyres were placed randomly in layers, and on every tyre layer sand was given. Pure tyres were placed randomly inside the mould and not compacted. Specimens with $40 \%$ tyres chips content were prepared by mixing sand and tyres chips before placing them in to the mould.

The influence of compaction was investigated. Two samples with $40 \%$ tyre content were prepared, one was compacted and the second one not. The compacted specimen reached the maximum deviator stress (equal to $251 \mathrm{kPa}$ at $9,6 \%$ of strain) earlier than the specimen prepared without compaction (233 $\mathrm{kPa}$ at $15,4 \%$ of strain), and the peak has a higher value for the compacted specimen. Resistance of not compacted sample is smaller because of big compressibility of the mixture. When sand matrix has higher density the resistance is greater. The density affects shear strength. Sand in the compacted specimen had a density of $1343 \frac{\mathrm{kg}}{\mathrm{m}^{3}}$, and in the not compacted specimen of $1137 \frac{\mathrm{kg}}{\mathrm{m}^{3}}$. However, the effect of these different densities wasn't well investigated in this testing program. Interpretation of the test results assumes homogeneity of the specimens.

As is shown on Figure 17 the volume variation is greatly affected by sand density. The volumetric behaviour of the sample with lower sand density is contractive. Volume of the specimen has been decreasing at the first part of the test, to increase in the second part, but at the end failed to reach the initial volume. The volume of the sample was greatly affected by confining pressure especially in a first part of the test.

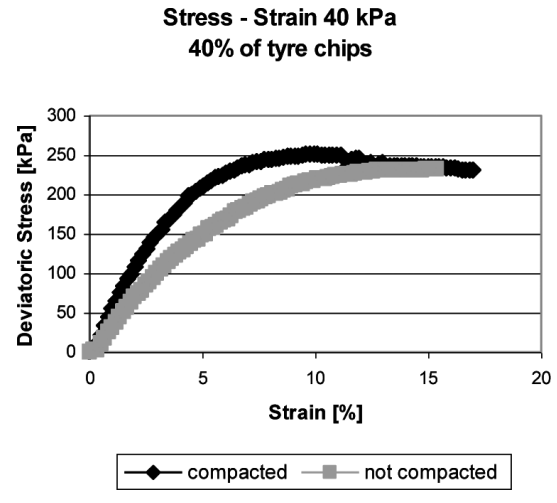

Fig. 16. Stress - strain relation, $40 \%$.

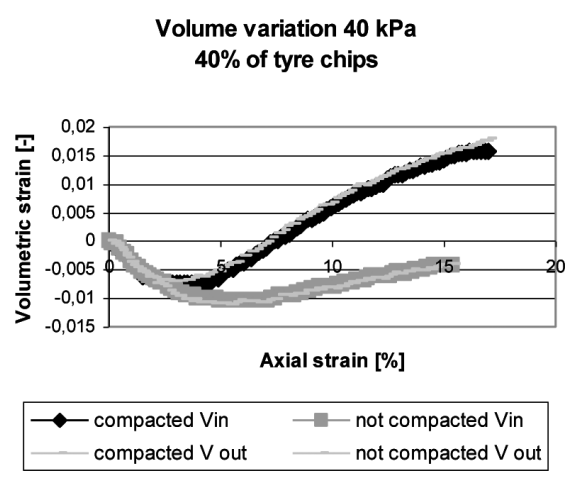

Fig. 17. Volume variation, $40 \%$. 


\subsection{THE INFLUENCE OF SATURATION}

The influence of saturation on the sample's resistance and volume variation was checked. Curves from Figure 18 are very similar. Only the dry sample under confining pressure $80 \mathrm{kPa}$ reached the maximum deviator stress earlier than saturated samples. The peak for this test has a lower value. The highest difference is equal to $66 \mathrm{kPa}$. It is hard to interpret, because only one dry test under confining pressure $80 \mathrm{kPa}$ was conducted.

Figure 19 shows that under a lower confining pressure $40 \mathrm{kPa}$ the behaviour of the dry sample is earlier dilatant. The volume of the sample increased earlier than for saturated test. A similar effect is observed for samples under $80 \mathrm{kPa}$, but this phenomenon is not as significant as for $40 \mathrm{kPa}$. Curves are almost the same, only one of saturated tests is more different.

Table 4

Summary of results.

\begin{tabular}{|c|c|c|c|c|}
\hline $\begin{array}{c}\text { Name of } \\
\text { curve }\end{array}$ & $\begin{array}{c}\text { Confining } \\
\text { pressure }\end{array}$ & Saturated/Dry & $\begin{array}{c}\text { Maximum } \\
\text { deviator } \\
\text { stress }\end{array}$ & Density \\
\hline- & {$[\mathbf{k P a}]$} & - & {$[\mathbf{k P a}]$} & {$\left[\frac{\mathrm{kg}}{\mathrm{m}^{3}}\right]$} \\
\hline $40 \mathrm{kPa} 1$ & 40 & saturated & 274 & 1368 \\
\hline $40 \mathrm{kPa} 2$ & 40 & saturated & 258 & 1393 \\
\hline $40 \mathrm{kPa} 3$ & 40 & saturated & 245 & 1372 \\
\hline $40 \mathrm{kPa}$ DRY & 40 & dry & 235 & 1372 \\
\hline $80 \mathrm{kPa} \mathrm{DRY}$ & 80 & dry & 400 & 1394 \\
\hline $80 \mathrm{kPa} 1$ & 80 & saturated & 466 & 1409 \\
\hline $80 \mathrm{kPa} 2$ & 80 & saturated & 545 & 1655 \\
\hline $80 \mathrm{kPa} 3$ & 80 & saturated & 442 & 1383 \\
\hline
\end{tabular}

Comparison between dry and saturated tests

$30 \%$ tyre chips

stress - strain relation
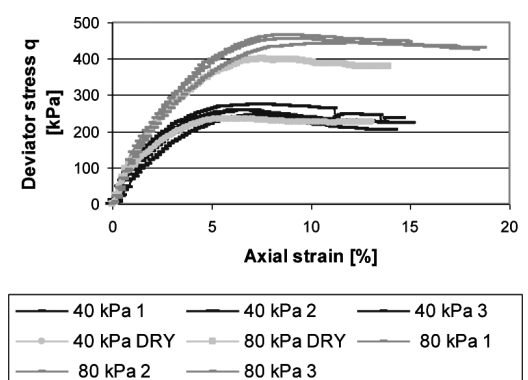

Fig. 18. Stress - strain relation, sat./dry.
Comparison between dry and saturated tests

$30 \%$ tyre chips

volume variation

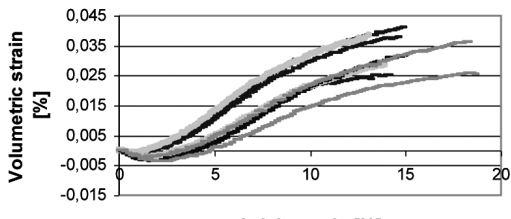

Axial starain [\%]

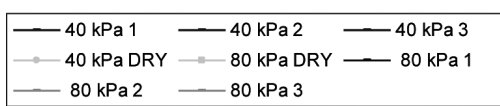

Fig. 19. Volume variation, sat./dry. 


\section{RESUlts}

\subsection{THE INFLUENCE OF CONFINING PRESSURE}

The strength of rubber tyres chips - sand mixture greatly depends on confining pressure and increases nearly linearly with increasing confining pressure. The relation between the maximum major principal stress $\sigma_{1}$, and the minor principal stress $\sigma_{3}$ is illustrated on Figure 20.

The relation between Sigma1 and Sigma3
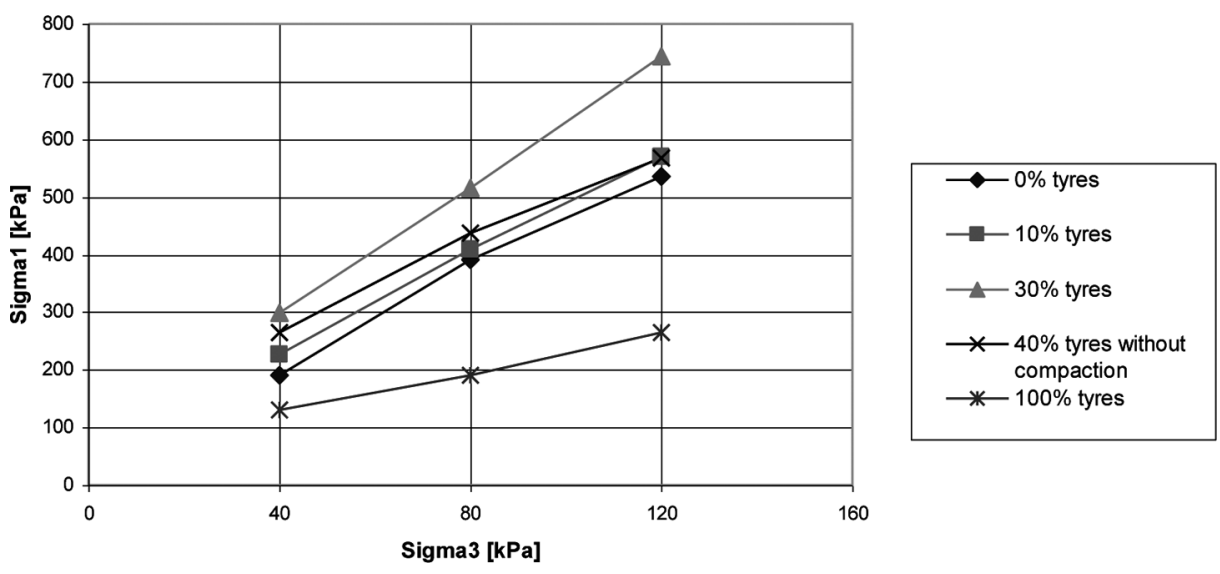

Fig. 20. The relation between $\sigma_{1}$ and $\sigma_{3}$.

The strongest mixture was found to be for $30 \%$ tyres content. The graph shows that shear strength is increasing with increasing percentage of tyre chips in the mixture until $30 \%$, and after decreases. Pure tyres and pure sand have lower strength than mixture. This is evidence that mixing those two components is beneficial. The best percentage is enclosed between $30 \%$ and $40 \%$ of tyres.

For $30 \%$, confining pressure has the greatest influence on shear strength. For a mixture with $30 \%$ tyre content the differences between $\sigma_{1}$ under confining pressure $40 \mathrm{kPa}$ and $120 \mathrm{kPa}$ is equal to $450 \mathrm{kPa}$, and for sand it is only $350 \mathrm{kPa}$. 
Sand

stress - strain

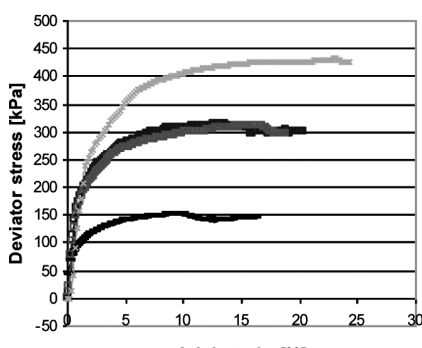

Axial strain [\%]

$$
\begin{aligned}
& -40[\mathrm{kPa}] 1-80[\mathrm{kPa}] 2 \\
& -80 \mathrm{kPa} 3 \longrightarrow 120 \mathrm{kPa} 4 \\
& \hline
\end{aligned}
$$

Fig. 21. Stress - strain relation, sand.

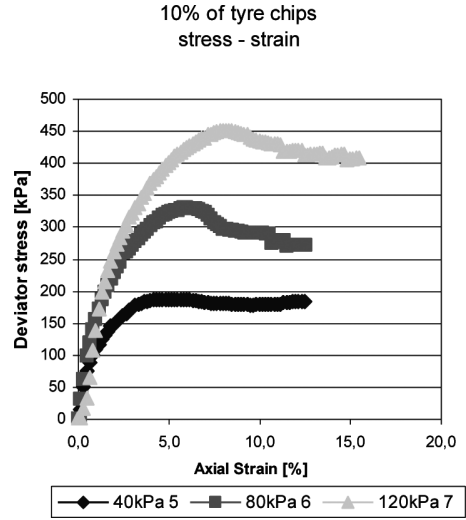

Fig. 23. Stress - Strain relation, $10 \%$.

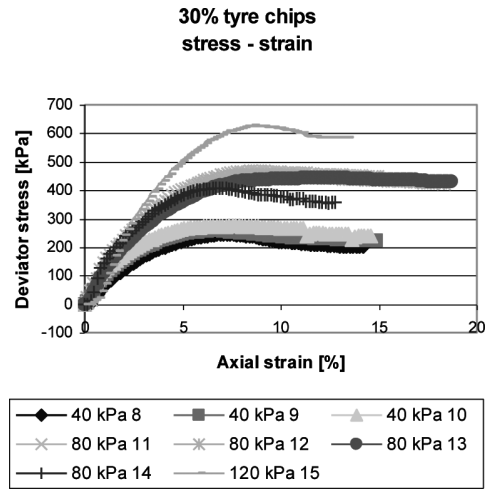

Fig. 25. Stress - strain relation, $30 \%$.
Sand

volume variation

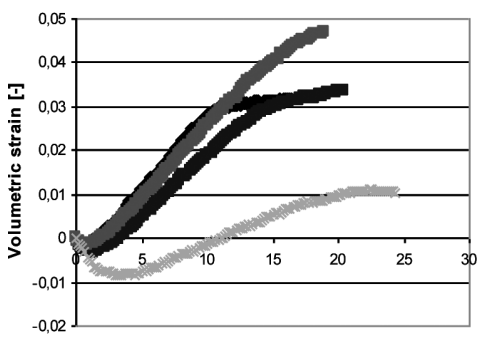

Axial strain [\%]

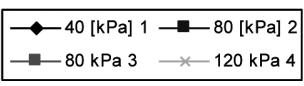

Fig. 22. Volume variation, sand.

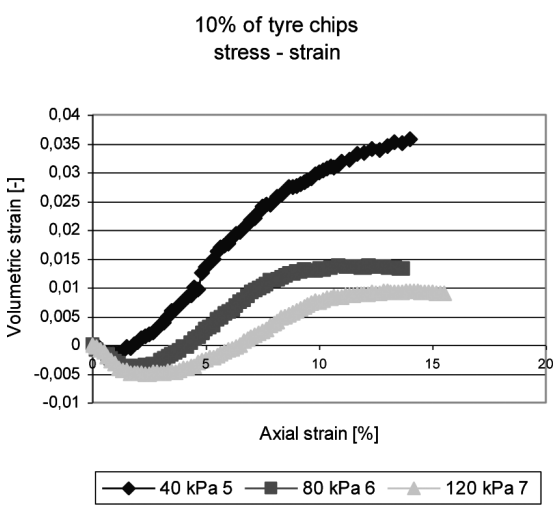

Fig. 24. Volume variation, $10 \%$.

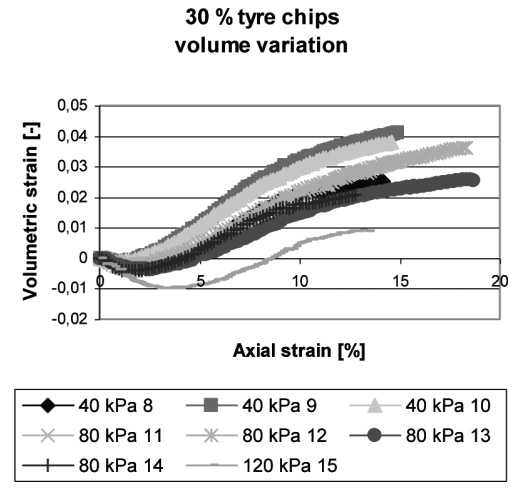

Fig. 26. Volume variation, $30 \%$. 

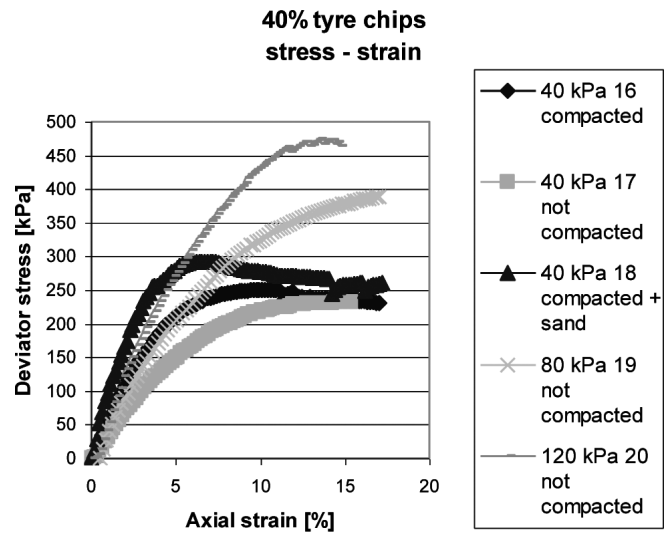

Fig. 27. Stress - Strain relation, $40 \%$.

\section{$40 \%$ tyre chips \\ volume variation}

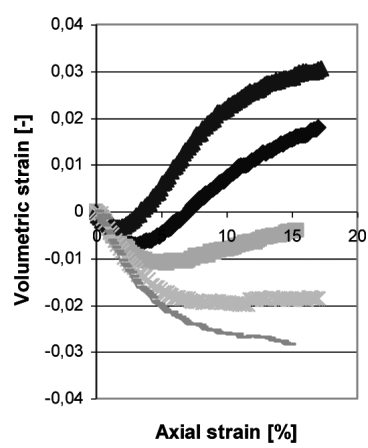

Fig. 28. Volume variation, $40 \%$.

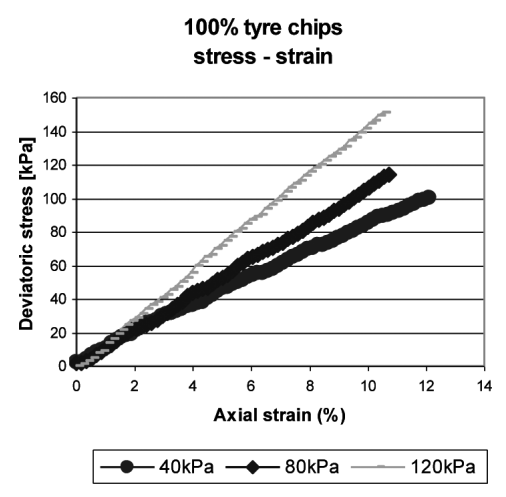

Fig. 29. Stress - Strain relation, $100 \%$.

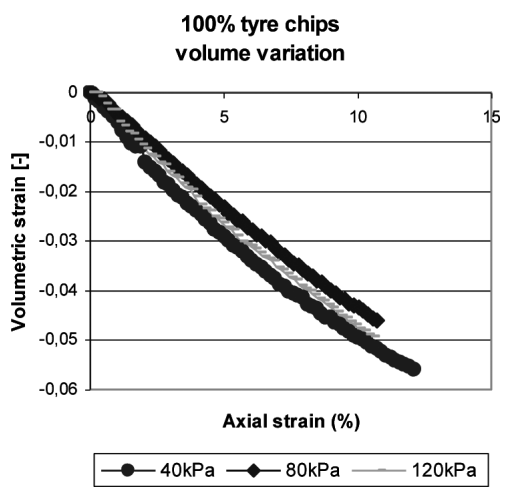

Fig. 30. Volume variation, $100 \%$.

\subsection{The Results ON SAMPLeS With $40 \%$ TyRe CONTENT}

Samples with $40 \%$ tyre chips content were prepared by using proportion in mass. Preparation in volume was difficult. For a confining pressure equal to $40 \mathrm{kPa}$ there were 3 tests conducted on specimens prepared in a different way. The first one was prepared without compaction, the second one with compaction, and the third one with compaction and at the top of the sample extra sand, which filled voids between tyre chips, was given. Results on those three specimens are shown on Figure 31 and 32. The curves of stress-strain relation for all specimens have well defined peak. 
Table 5

Summary of results.

\begin{tabular}{|c|c|c|c|c|c|c|c|c|}
\hline $\begin{array}{c}\text { Test } \\
\text { number }\end{array}$ & $\begin{array}{c}\text { Name of } \\
\text { curve }\end{array}$ & $\begin{array}{c}\text { Heigh of } \\
\text { the sample }\end{array}$ & $\begin{array}{c}\text { \% of } \\
\text { tyre } \\
\text { chips in } \\
\text { volume }\end{array}$ & $\begin{array}{c}\text { \% of } \\
\text { tyre } \\
\text { chips in } \\
\text { volume }\end{array}$ & $\begin{array}{c}\text { Confining } \\
\text { pressure }\end{array}$ & $\begin{array}{c}\text { Strain } \\
\text { at } \\
\text { peak }\end{array}$ & $\begin{array}{c}\text { Maximum } \\
\text { deviator } \\
\text { stress }\end{array}$ & $\begin{array}{c}\text { Density } \\
\text { of the } \\
\text { sample }\end{array}$ \\
\hline- & - & {$[\mathrm{cm}]$} & {$[\%]$} & {$[\%]$} & {$[\%]$} & {$[\%]$} & {$[\mathrm{kPa}]$} & {$\left[\frac{\mathrm{kg}}{\mathrm{m}^{3}}\right]$} \\
\hline 16 & compacted & 29,7 & 40 & 43,8 & 40 & 9,6 & 251 & 1259 \\
\hline 17 & $\begin{array}{c}\text { not } \\
\text { compacted }\end{array}$ & 30,2 & 40 & 39,7 & 40 & 15,4 & 233 & 1142 \\
\hline 18 & $\begin{array}{c}\text { compacted } \\
\text { + sand }\end{array}$ & 30,5 & 37,3 & 43,5 & 40 & 6,2 & 292 & 1341 \\
\hline
\end{tabular}

Stress - Strain $40 \mathrm{kPa}$ $40 \%$ of tyre chips

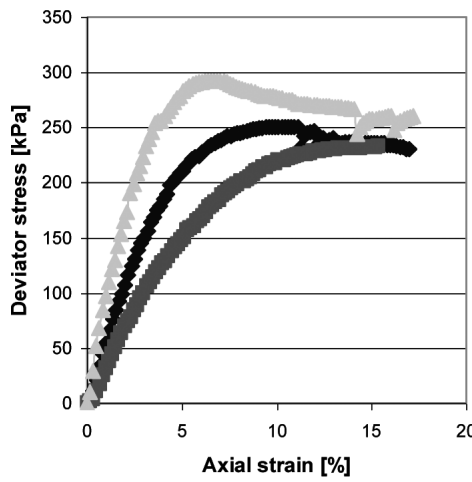

\section{$\neg$ compacted}

- not compacted

compacted+sand on the top ( $44 \%$ tyre)

Fig. 31. Stress - strain relation, $40 \%$.

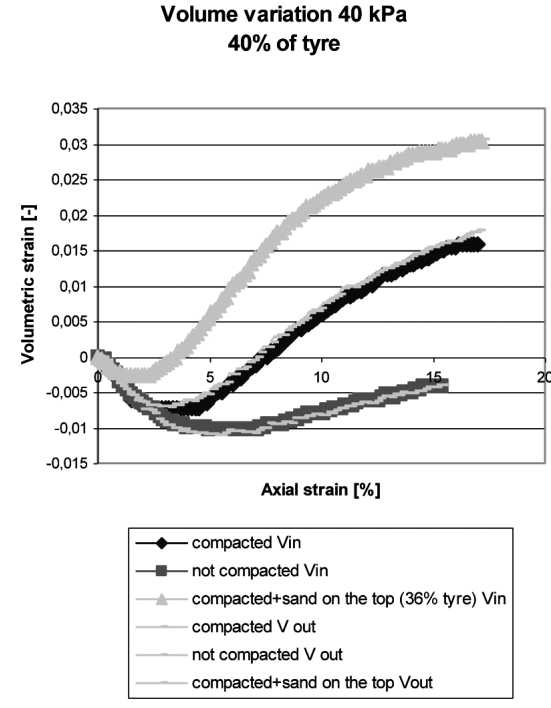

Fig. 32. Volume variation, $40 \%$.

Both, maximum deviator stress and volume variation depend on sand density. For not compacted sample the sand density was $1137 \frac{\mathrm{kg}}{\mathrm{m}^{3}}$, for compacted sample it was $1343 \frac{\mathrm{kg}}{\mathrm{m}^{3}}$, and for compacted sample with $43,5 \%$ of tyres density of sand was equal to $1489 \frac{\mathrm{kg}}{\mathrm{m}^{3}}$. With increasing sand density the slope of stress - strain relation curve becomes sharper, the resistance of the sample is increasing. For a higher density. the peak was reached earlier, at smaller strain.

From Figure 32 it can be read that dilatant behaviour of specimens prepared with compaction is significantly different from that prepared without compaction. Samples 
with higher sand density show more dilatant behaviour. At the beginning of the test, the decrease of volume was much smaller than for samples with comparatively low density. When the specimen was not compacted and the density was low, the behaviour was contractive.

Results from other investigations indicate that the influence of sand matrix relative density is highly dependent on the tire shred content in the mixture. For example, the shear strength of specimens prepared with pure sand at low relative density is expectedly lower than the shear strength of specimens prepared with pure sand at higher relative density. As the tyre shred content increases but below 30\%, the shear strength is still influenced by the sand matrix relative density, but not as significantly as in the case of pure sand. A comparison of the shear strength obtained for specimens with $30 \%$ tyre content indicates that an increase in the sand density does not lead to significant increases in the shear strength of tyre shreds - sand mixture, at least for tyre shred contents in the vicinity of $30 \%$. These result suggest that, for practical purpose, it may not be effective to compact tyre shred - soil mixtures to high densities ("Behaviour of tire shered - sand mixtures", Jorge G. Zornberg, Alexandre R. Carbal and Chardphoom Viratjandr).

The weight of the mixture should be considered in selecting the mixing proportions because increasing the sand density increases the weight of the mixed material.

4.3. The INFLUENCE OF TYRE ChIPS CONTENT IN THE MiXTURE

Influence of the tyre content on the shear strength

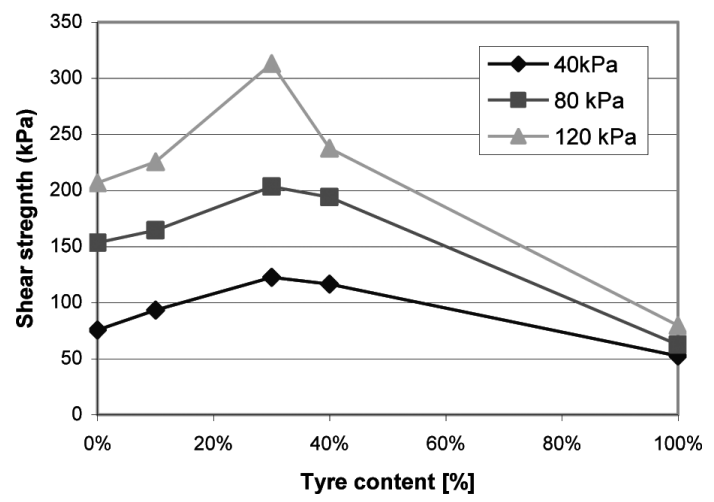

Fig. 33. Influence of tyre chips content on shear strength.

Figure 33 shows the influence of tyre chips content in mixture on the shear strength. Samples with $30 \%$ tyre chips content have the highest shear strength which reached more then $300 \mathrm{kPa}$. Shear strength increases with increasing percentage of tyre chips in the mixture until $30 \%$. After $30 \%$ a decrease is observed. 
Sand has more strength than pure tyre chips. Figure 33 shows that sand cooperates with tyre chips. The mixture has the best properties. After 30\% mixture stars to behave more like pure tyre chips then like sand.

The graph shows that the influence of tyre chips on sand is beneficial. Tensile forces develop within the tyre chips, leading to increased overall shear strength of the mixture. These results indicate that using tyre chips in the mixture with sand should be considered not only like a way of reusing "end of life tyres", but also as an approach to enhance the mechanical properties of geotechnical structures.

These results provide potential guidelines for selecting the optimum mixing proportions between sand and tyre chips. However, the weight of the mixture should be considered in selecting the mixing proportions because increasing the sand content increases the weight of the mixed material.

Results show that deviator stress - strain relation of tyre - sand specimens always has a well defined peak. From figure 36 and table 6 it can be read, that the highest deviator stress, almost $300 \mathrm{kPa}$, was reached by sample with $37,3 \%$. For specimens with tyre content lower than $40 \%$, with increasing tyre percentage the maximum deviator stress is increasing (Figure 35). Due to high deformations of rubber chip particles, the magnitude of strain, at the peak deviator stress, increased with an increasing proportion of tyre chips in the mixture, excluding pure sand (Figure 34).

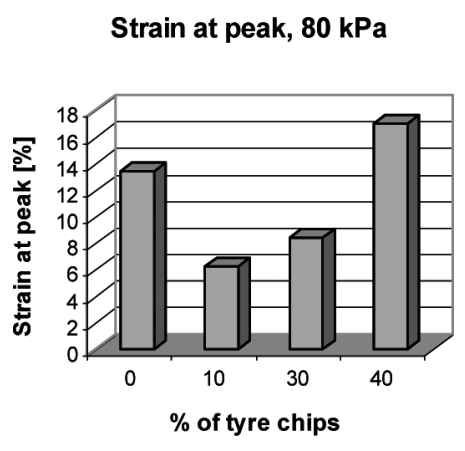

Fig. 34. Strain at peak, $80 \mathrm{kPa}$.

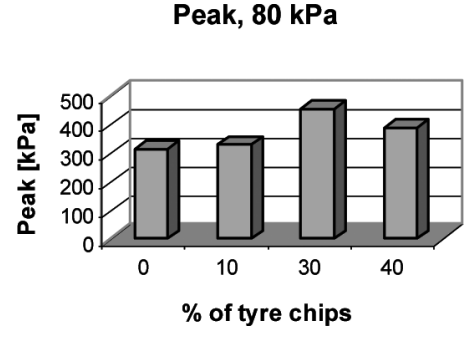

Fig. 35. Peak, 80 kPa.

Tyre content affects greatly the shape of stress - strain relation curve. With increasing tyre content in the mixture the slope of this curve is becoming to be less rapid. The point of bend is reached at a lower strain. The curse of stress - strain relation of pure tyre chips is fully linear, without banding point.

The deformation characteristics of tyre chips - sand mixture are relatively similar to sand. Deformation of the rubber chips - sand mixture can be classified in to two types: deformation of tyre chips particles and rearrangement of the particles. This is different from the common characteristics of soil wherein deformation mainly occurs from the relocation of particles, with negligible deformation of the soil particle. Thus, the critical state for the mix material is difficult to determine because of the deformation 
of tyre chips particles at the steady state. The effect of rearrangement of particles on stress - strain relation curve is visible for example on Figure 36 (curve of $37,3 \%$ of tyre chips). After shearing, when stabilization was almost reached there were some dislocations of mixture components.

Table 6

Summary of results of all percentages.

\begin{tabular}{|c|c|c|c|c|c|}
\hline $\begin{array}{c}\text { \% of tyre } \\
\text { chips in } \\
\text { volume }\end{array}$ & $\begin{array}{c}\text { Real \% of } \\
\text { tyre chips } \\
\text { in mass }\end{array}$ & $\begin{array}{c}\text { Confining } \\
\text { pressure }\end{array}$ & Peak & Strain at peak & Density \\
\hline$[\%]$ & {$[\%]$} & {$[\mathbf{k P a}]$} & {$[\mathbf{k P a}]$} & {$[\%]$} & {$[\mathbf{k g} / \mathbf{m 3}]$} \\
\hline 0 & 0 & 40 & 151 & 9,4 & 1496 \\
\hline 0 & 0 & 80 & 313 & 13,4 & 1475 \\
\hline 0 & 0 & 120 & 413 & 11,3 & 1468 \\
\hline 10 & 9 & 40 & 187 & 4,5 & 1403 \\
\hline 10 & 9 & 80 & 329 & 6,2 & 1431 \\
\hline 10 & 9 & 120 & 451 & 7,8 & 1431 \\
\hline 30 & 25,5 & 40 & 258 & 6,4 & 1502 \\
\hline 30 & 25,5 & 80 & 454 & 8,4 & 1655 \\
\hline 30 & 25,5 & 120 & 626 & 8,6 & 1363 \\
\hline 43,6 & 37,3 & 40 & 292 & 6,2 & 1489 \\
\hline 39,7 & 40 & 40 & 233 & 15,4 & 1142 \\
\hline 43,4 & 40 & 80 & 388 & 17 & 1250 \\
\hline 41,3 & 40 & 120 & 475 & 14,3 & 1185 \\
\hline
\end{tabular}

Stress - Strain $40 \mathrm{kPa}$

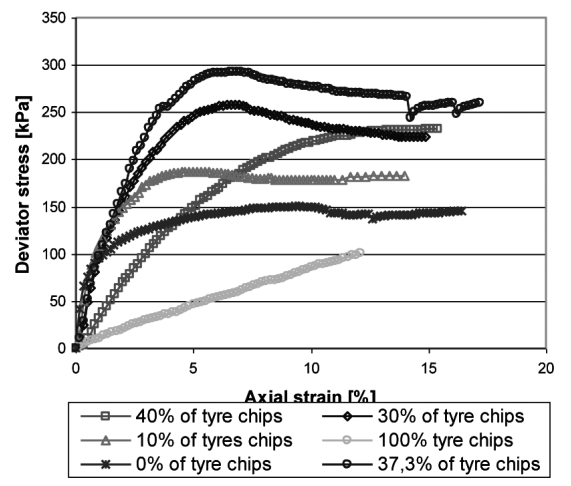

Fig. 36. Stress - strain relation, $40 \mathrm{kPa}$.
Volume variation $40 \mathrm{kPa}$
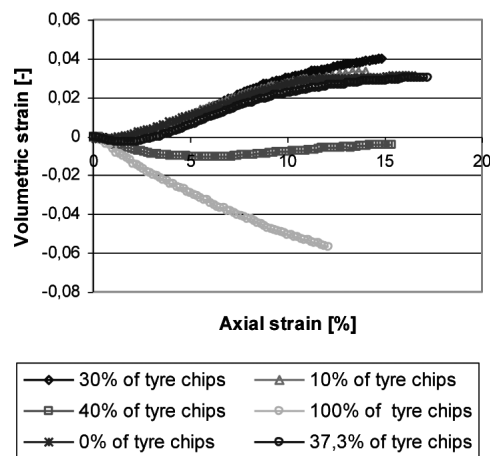

Fig. 37. Volume variation, $40 \mathrm{kPa}$. 
Tyre content has no big influence on volume variation, as all graphs show of volume variation, for all confining pressures. The only observable influence, is the influence of compaction. Specimens of pure tyre chips and specimens of $40 \%$ of tyre chips were not compacted. Their behaviour is contractive. since tyre chips compaction is impossible for high tyre contents (compaction causes segregation) we can say that with increasing tyre content the behaviour of mixture is more and more contractive.

Mixing sand with tyre chips not only increased the strength but also improved deformation characteristics of the mixed material.

Stress - Strain $80 \mathrm{kPa}$

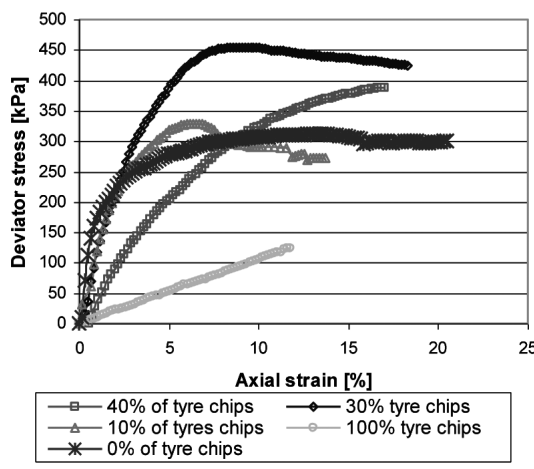

Fig. 38. Stress - strain relation, $80 \mathrm{kPa}$.

Stress - Strain $120 \mathrm{kPa}$

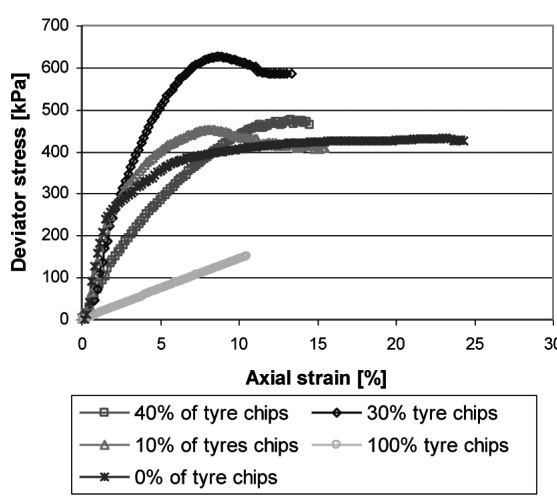

Fig. 40. Stress - strain relation, $120 \mathrm{kPa}$.
Volume variation $80 \mathrm{kPa}$
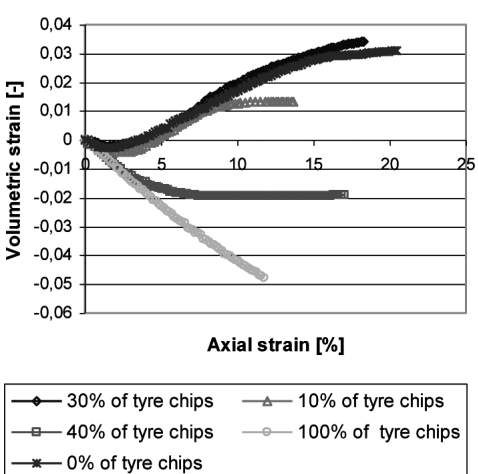

Fig. 39. Volume variation $80 \mathrm{kPa}$.

Volume variation $120 \mathrm{kPa}$

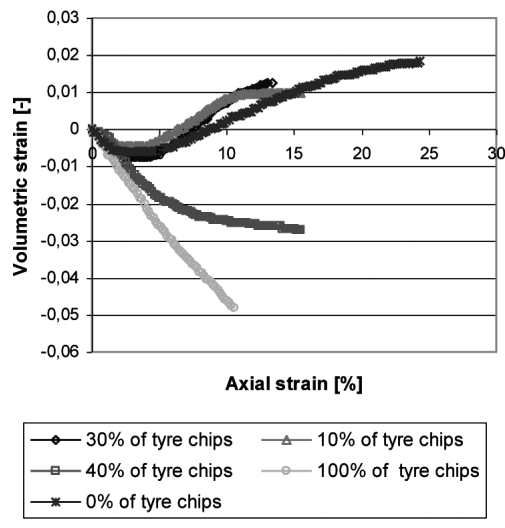

Fig. 41. Volume variation $120 \mathrm{kPa}$. 
4.4. The COMPARISON BetWeEN TESTS CONDUCTED ON THE SAME TYPE OF SAMPLE, AND IN THE SAME CONDITION

Some tests were made in the same condition, and on the same type of sample were compared to check the differences between them. Two tests on sand samples with 2 membranes under confining pressure $80 \mathrm{kPa}$ were conducted. The difference between peaks from those two tests (Figure 42) is equal to $3 \mathrm{kPa}$. for the first tests is was $310 \mathrm{kPa}$ and for second test $313 \mathrm{kPa}$. The biggest difference between those two curves is equal to $10 \mathrm{kPa}$. for test $\mathrm{nr} 1$ the peak was reached at $13,4 \%$ of strain and for test $\mathrm{nr} 2$ at $15,1 \%$ of strain. The curves are almost identical. There is not a big difference between them.

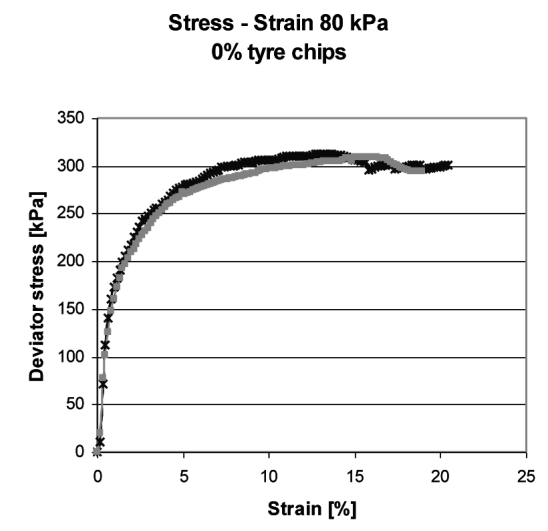

* $0 \%$ tyre chips $80 \mathrm{kPa} 1 \longrightarrow-0 \%$ tyre chips $80 \mathrm{kPa} 2$

Fig. 42. Stress - strain relation, sand.

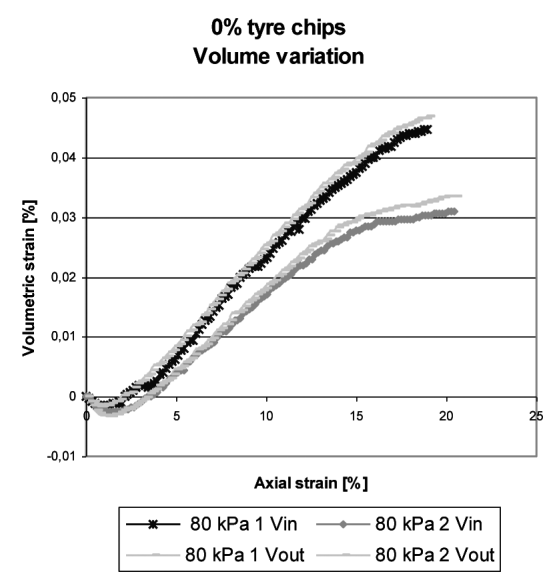

Fig. 43. Volume variation, sand.

Figure 43 presents volume variation for two sand samples. This graph shows that there were some differences between those specimens. It could have been caused by little difference in density. For test number 1 it was $1475 \frac{\mathrm{kg}}{\mathrm{m}^{3}}$ and for test number $2-$ $1501 \frac{\mathrm{kg}}{\mathrm{m}^{3}}$.

Table 7 shows results on four test conducted on samples with $30 \%$ tyre content. The biggest difference between maximum deviator stresses is equal to $45 \mathrm{kPa}$, and the biggest difference between strains at peaks is equal to $4,2 \%$. For sand it was $3 \mathrm{kPa}$ and $1,7 \%$.

The presented figures show that differences between results in the samples with $30 \%$ tyre chips content are bigger than for sand samples. During preparation of the sample, tyre chips were placed accidentally. Sand was filling voids in a different way. Sand samples were more similar. 
Summary of results.

\begin{tabular}{|c|c|c|c|c|}
\hline $\begin{array}{c}\text { Test } \\
\text { number }\end{array}$ & $\begin{array}{c}\text { \% of } \\
\text { tyre } \\
\text { chips }\end{array}$ & $\begin{array}{c}\text { Confining } \\
\text { pressure }\end{array}$ & $\begin{array}{c}\text { Maximum } \\
\text { deviator } \\
\text { stress }\end{array}$ & Density \\
\hline- & {$[\%]$} & {$[\mathrm{kPa}]$} & {$[\mathrm{kPa}]$} & {$\left[\mathrm{kg} / \mathrm{m}^{3}\right]$} \\
\hline $\mathbf{1 1}$ & 30 & 80 & 466 & 1409 \\
\hline $\mathbf{1 2}$ & 30 & 80 & 454 & 1655 \\
\hline $\mathbf{1 3}$ & 30 & 80 & 443 & 1383 \\
\hline $\mathbf{1 4}$ & 30 & 80 & 487 & 1352 \\
\hline
\end{tabular}

$30 \%$ tyre chips

stress - strain relation

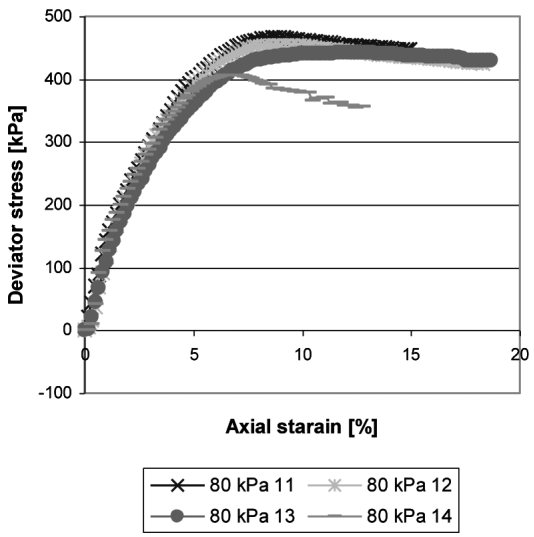

Fig. 44. Stress - strain, $30 \%$ tyre chips.

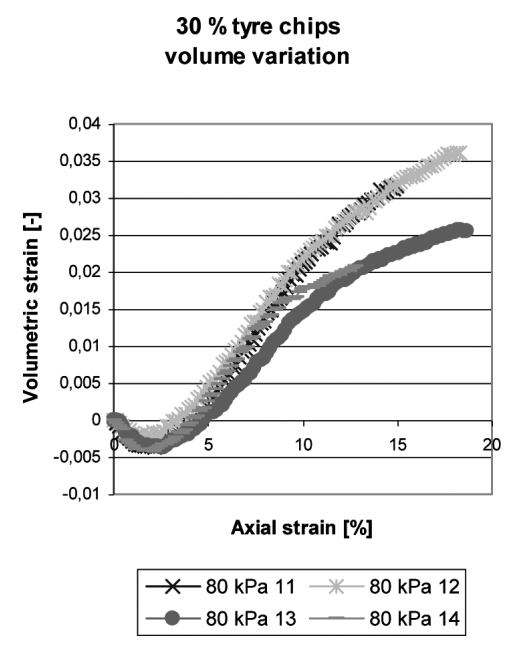

Fig. 45. Volume variation, $30 \%$.

\subsection{COHESION AND INTERNAL FRICTION ANGLE}

To determine the fiction angle $\phi\left[{ }^{0}\right]$, and cohesion $\mathrm{c}[\mathrm{kPa}]$ a computer program named "Rockdata" was used. This is a program used to analyse strength data, which draws Mohr Coulomb circles. The example of result is shown on Figure 46.

Figure 47 shows that the highest friction angle was reached by a sample with $30 \%$ tyre content. This figure also shows, that $\phi$ increases with increasing percentage of tyre chips until $30 \%$, and after decreases. It is suspected that the percentage of tyre chips which has the best friction angle is enclosed between $30 \%$ and $40 \%$.

In figure 47, a thin line between values of friction angle of pure sand and of friction angle of pure tyre chips is plotted. This line id called a base line. According to this graph, the composite shear strength involves the contribution of two mechanisms. The first one is the internal shear mechanism developed among individual tyre chips and sand grains. The second one is the reinforcement mechanism due to the tensile 


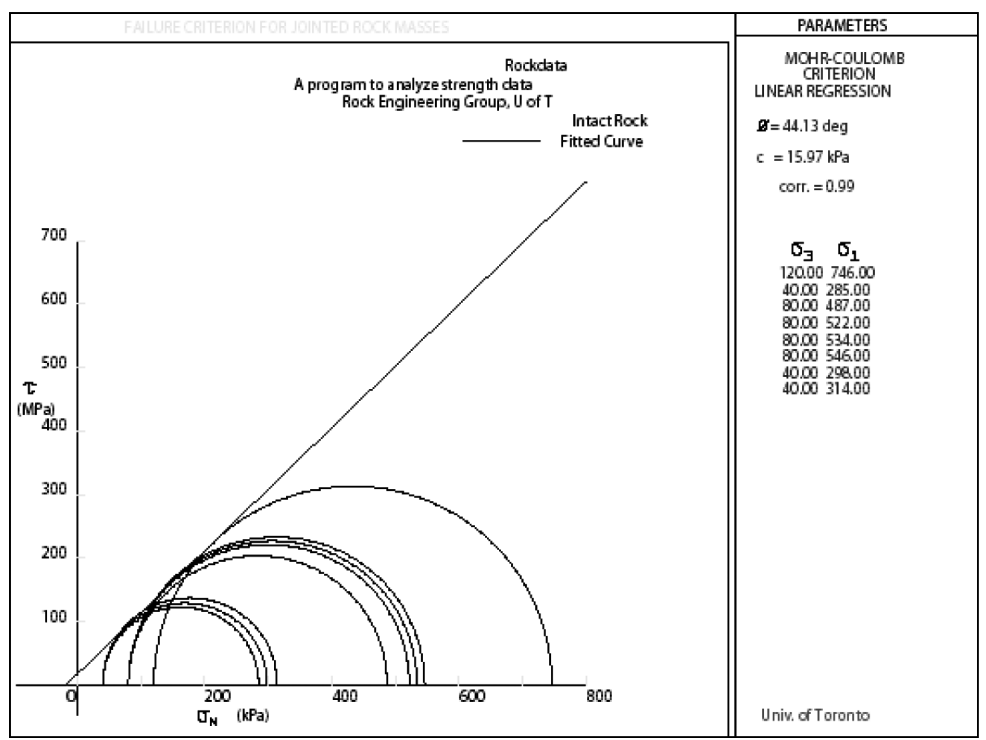

Fig. 46. Result on samples with $30 \%$ tyre chips content from "Rockdata" program.

forces inducted within the tyre chips. The shear strength of pure sand is higher than that of pure tyre chips. for intermediate tyre chips contents, contribution by internal shear mechanism is the weighted average based on the pure sand and pure tyre chips shear strength. The contribution of reinforcement mechanism leads to mixture shear strength values above the base line - shear strength line. These results are consistent with data analysed in the article "Behaviour of tyre shred - sand mixtures" by Jorge G. Zornberg, Alexandre R. Cabral, and Chardphoom Viratjande.

Figure 48 shows that cohesion increases with increasing tyre chips content, but for pure tyre chips has a lower value than for a mixture with $30 \%$ tyre content. It is evidence for cooperation between sand and tyre chips. This graph shows a similar principle as that from figure 47. For sand cohesion is expected to be zero.

Humpherey et. al (1993) reported friction angles for pure tyre shreds ranging from $19^{0}-25^{0}$ and cohesion intercepts ranging from 4,3 to $11,5 \mathrm{kPa}$, and Foose et. al. (1996) reported friction angles for pure tyre shreds specimens of approximately $30^{\circ}$ and cohesion of about $3 \mathrm{kPa}$. Results from this investigation are different than the data mentioned above. It could be caused by obtaining the shear strength at $10 \%$ of strain for pure tyre chips, and the different shape of tyre shreds.

The results indicate that the shear strength increases with increasing tyre chips content, reaches the maximum for $30 \%$, and then decreases for tyre chips contents beyond this value. This is evidence that the soil reinforcement mechanism takes place within the tyre chips - sand composite. 
The influence of tyre chips content on friction angle

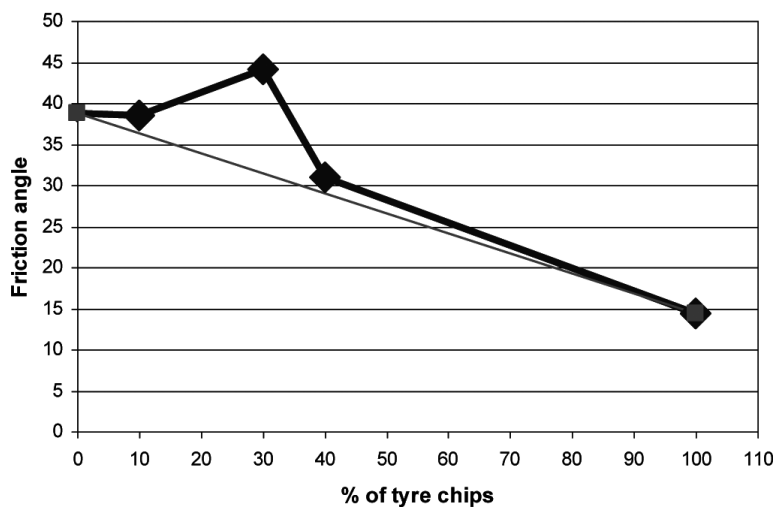

Fig. 47. The influence of tyre chips content on friction angle (Friction angle for pure tyre chips was determined using stress at $10 \%$ of strain.

For other percentages maximum stress was used.)

The influence of tyre chips content on cohesion

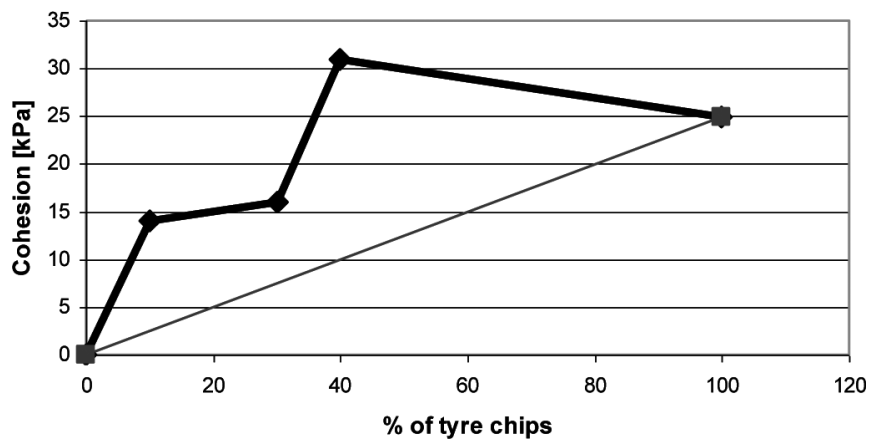

Fig. 48. The influence of tyre chips on cohesion c (Cohesion for pure tyre chips was determined using stress at $10 \%$ of strain.

For other percentages maximum stress was used.)

\section{Conclusion}

Traixial tests were conducted on pure tyre chips, tyre chips - sand mixture and sand. The results show that the influence of tyre chips content on the stress - strain, and volumetric strain behaviour is significant.

The shear strength of tyre chips - sand composite is affected by tyre chips content, reaches a maximum for $30 \%$, and then decreases for tyre chips contents beyond this value. The effect on shear strength of tyre chips content in mixture is beneficial. The optimum percentage of tyre in composite is enclosed between $30 \%$ and $40 \%$. 
All mixture and sand specimens had a well defined peak. The stress - strain relationship of pure tyre chips was approximately linear and the peak wasn't observed. With an increasing percentage of tyre, the value of strain at the peak was increasing. The behaviour of the mixture changes from sand-like to tire-like at tyre chips content enclosed between $30 \%$ and $40 \%$.

The density of sand and compaction has an influence on behaviour of the mixture. Resistance of a not compacted sample is smaller because of big compressibility of the mixture. When the sand matrix has higher density the resistance is greater.

For all types of specimens shear strength is strongly affected by confining pressure. Shear strength is increasing with increasing confining pressure, and the strain at peak is increasing too.

The volumetric behaviour of specimens with tyre content $\leq 30 \%$ is dilatant, and fully contractive behaviour is obtained in specimens with tyre chips content higher than $30 \%$. The influence of tyre chips percentage on composite is not noticeable for tyre chips content lower than $30 \%$ or equal to $30 \%$. Volume variation of mixture and sand is affected by confining pressure, but not for pure tyre, because of big compressibility of tyre chips.

The effect of the number of membranes and saturation is negligible.

Sand density is highly dependent on the tyre chips content. With an increasing percentage of tyre chips in the mixture density is decreasing. Compaction of specimens with tyre content higher than $30 \%$ causes segregation of components.

These results show that soil reinforcement mechanisms takes place within the tire chips sand mixture. Tyre chips mixed with sand increase shear strength, and improve deformation characteristics of the mixture. These results indicate that the use of tyre chips within sand should be considered not only as an alternative for beneficial reuse of large number of tyres, but also as an approach to enhance the mechanical properties of geotechnical structures.

\section{REFERENCES}

1. M. Kowalczyк, "Reuse of end of life tyres. Tyre chips-sand mixture mechanical study", Gdansk University of Technology, Department of Civil and Environmental Engineering, Specialisation Geotechnics, Gerenoble 2005.

2. "Annual Activity Report 2004-2005", European association of the rubber industry, BLIC.

3. www.chelseacenter.org.

4. www.epa.gov, http://www.rpa.gov/epaoswe/non-hw/muncpl/tires/civil eng.htm, Civil engineering applications.

5. "Post - consumer tyres in the expanded European Union", Dr Valerie V. L. Shulman Secretary general, the European Tyre Recycling Association, UNOP, Cyprus, 5 April 2004.

6. http://www.uwgeotech.org/pdf/49\%20Benson\%2095\%20tire\%20chip\%20article.pdf, Using scrap tyre in civil and environmental construction", Craig H. Benson.

7. "Promotion of Responsible Management of used tyres by the Tyre Industry", BLIC, November 2003. 
8. "Tire Product Stewardship Draft Action Plan", State of California, University of Massachusetts.

9. "Management of End - of - Life Tyres", FIRECONE, Andrew Sweet, 16 January 2004.

10. US SCRAP TIRE MARKET 2001, RUBBER manufactures association, www.rma.org.

11. "Environmental Impacts of Recycled Rubber in Light Fill Applications, Summary and Evaluation of Existing Literature", CHELSA CENTER FOR RECYCLING AND ECONOMIC DEVOLOPMENT, University of Massachusetts, August 1998.

12. A. SZULESKa, "TYRE - SAND MIXTURES STUDY FOR GEOTECHNICAL GABION APPLICATION", Gdansk University of Technology, Faculty of Hydro and Environmental Engineering, Department of Geotechnics., Grenoble, July 2004.

13. "Strength and deformation characteristics of shredded rubber tire - sand mixtures", Sompote Youwai and Dennes T. Bergado 2003 NRC Canada.

14. "Behaviour of tire shred - sand mixtures", Jorge Zonenberg, Alexandre R. Cabral and Chardphoom Viratjandr, 2004 NRC Canada.

15. "Influence of Optimized Tire Shreds on Shear Strength Parameters of Sand", Mahmoud Ghazavi and Masouud Amel Sakhi.

16. "Triaxial Deformination of Shear Strength of Tire Chips" by Wei Y. Wu, Associate Member, ASCE, Christopher C. Benada, P.E., and Robert F. Cauley, P. E., Member, ASCE. 